\title{
Encapsulated Abdominal Fat Necrosis
}

\section{Citoesteatonecrose Abdominal Encapsulada}

Rita MAGALHÃES $\otimes^{1}$, Juliana OLIVEIRA ${ }^{1}$, Sofia CARIDADE ${ }^{1}$

Acta Med Port 2016 Oct;29(10):673-673 - http://dx.doi.org/10.20344/amp.7216

Keywords: Abdominal Fat; Abdominal Pain; Fat Necrosis; Neoplasms.

Palavras-chave: Dor Abdominal; Gordura Abdominal; Necrose Gordurosa; Neoplasias.
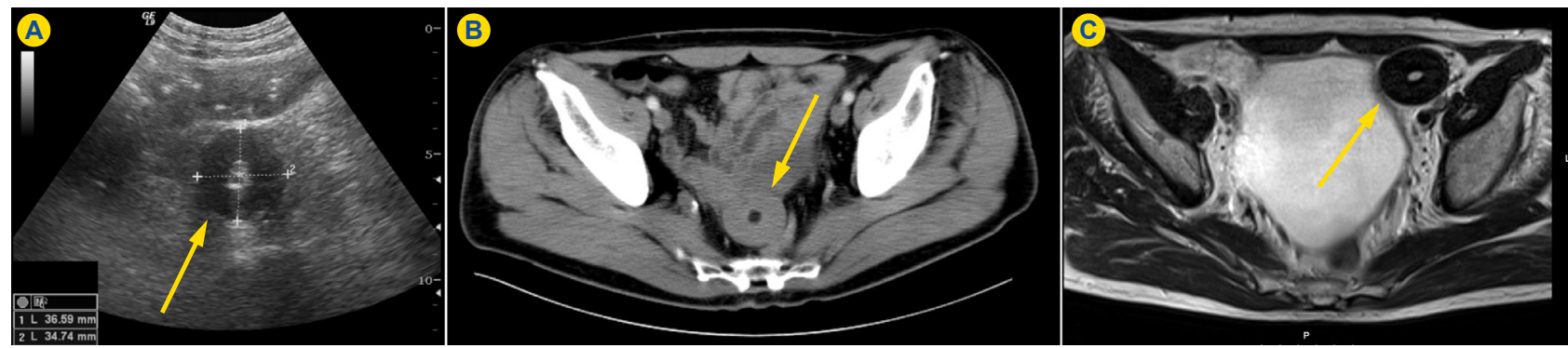

Figure 1 - Abdominal nodule seen in ultrasound (A), CT scan (B), MRI (C).

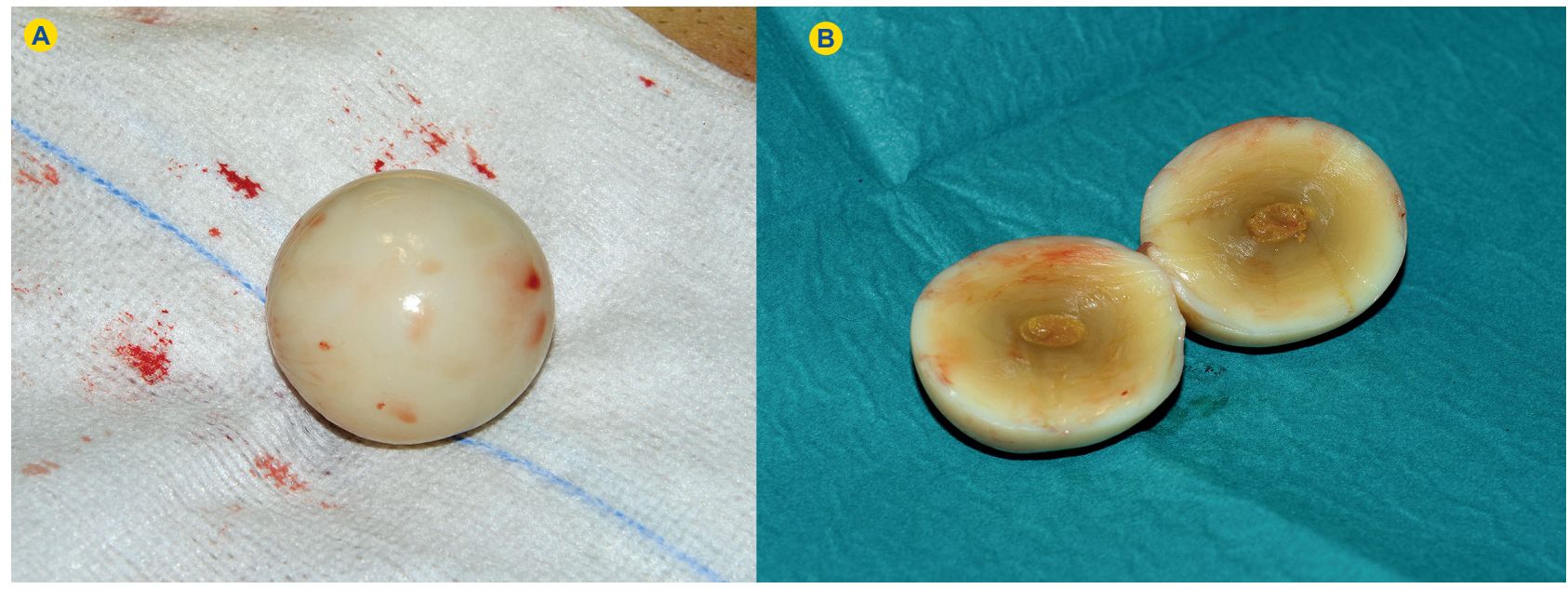

Figure 2 - Macroscopic view of the abdominal nodule (A), and of its center (B)

A 59 year old man, without history of pancreatitis or abdominal surgery, presented with a three-month evolving abdominal, persistent, diffuse, colicky, lasting pain, associated with significant weight loss and anorexia. Abdominal ultrasound, computed tiomography scan and magnetic resonance imaging (Fig.s 1A, 1B, 1C) showed the presence of nodular formation with 3.8 centimeters, between the bladder and rectum, solid, with an adipose center and regular contour, apparently moving in successive imaging, leading our thought to a possible foreign body or liposarcoma. ${ }^{1}$ During exploratory laparoscopy, a $26 \mathrm{~g}$ nodule was extracted, with $4 \mathrm{~cm} \times 3.6 \mathrm{~cm} \times 3.2 \mathrm{~cm}$ and a smooth, pale outer surface (Fig. 2A). In the middle we saw a yellowish central area of one cm (Fig. 2B). Histology revealed it had a central adipose tissue with fat necrosis, surrounded by dense fibrous tissue of collagen. During one year of follow-up, the patient remained asymptomatic.

\section{REFERENCES}

1. Kamaya A, Federle MP, Desser TS. Imaging manifestations of abdominal fat necrosis and its mimics. Radiographics. 2011;31:2021-34.

1. Serviço de Medicina Interna. Hospital de Braga. Braga. Portugal.

$\square$ Autor correspondente: Rita Magalhães. rita.sc.magalhaes@hotmail.com

Recebido: 18 de novembro de 2015 - Aceite: 08 de março de 2016 | Copyright $\odot$ Ordem dos Médicos 2016 